\title{
Rebellion as a Means of Temporary Escape from Disillusionment as Reflected in David Hare's Teeth ' $n$ ' Smiles
}

\author{
Imren Yelmis \\ Hacettepe University \\ E-mail: imrenyelmis@gmail.com
}

Doi:10.5901/ajis.2013.v2n3p437

\begin{abstract}
Subcultures mainly emerge as a resistance to the status quo/ the Establishment. They create their own discourses/ languages and an escapist dream world of their own in which, they think, they will be momentarily happy, and will symbolically vomit their anger, as if they were in a carnival, as Bakhtin argues, where many voices are heard, and which deconstructs the norms of the Establishment. In relation to this idea, it might be argued that, similarly, rock bands' aggressive manners while singing reflect their rebellious nature and resistance towards the mainstream culture. In a way, they exhibit carnivalesque characteristics through defying the rules with their own ways. David Hare, in his Teeth ' $n$ ' Smiles (1975), which is set in the late 1960s, tells a similar rock band which mirrors its rebellious nature through rock ' $n$ ' roll songs. The aggressive nature of this band and their songs, are, in fact, reflective of their disillusionment and may be an answer to the events or situations observed not only in Britain but also abroad such as May 1968 French students' rebellion and Britain's loss of power after World War II. It is also important to state that the frustrations observed in the 1960s as reflected in the play, in fact, reflect the frustration that Hare himself experienced when he was a student at Cambridge. In the light of the above-mentioned statements, this paper aims to discuss the relationship between Bakhtin's idea of carnivalesque and the rock ' $n$ ' roll band in Hare's Teeth ' $n$ ' Smiles, in terms of exhibiting their rebellious nature and of a momentary escape from frustrations resulting from the errors of the Establishment.
\end{abstract}

Keywords: Teeth 'n' Smiles, Bakhtin, carnival, carnivalesque, rebellion, subcultures, temporary escape, disillusionment

"May '68 [...] gave me a desperation I still have" (Brenton, cited in Billington, 2007, p. 215)

David Hare, who was born on 5 June 1947, and who graduated from Cambridge University in 1968, has reflected in his works his disillusionment with not only the political situation of the Conservatives and the Liberals (Rusinko, 1989, p. 135) but also social issues in Britain and throughout Western Europe. In relation to this, his works may be thought as a call for political and social change. Raymond Williams' Marxist teachings had great impact upon Hare in forming his political views (Billington, 2007, p. 215). In fact, as Presada points out, Hare "embarked on attacking the humanist tradition of social drama, refashioning the realism of the elder playwrights (such as Osborne and Wesker) from a Marxist perspective" (para. 2). Hare, like other political playwrights such as Edward Bond, Howard Brenton, David Edgar, John McGrath and Trevor Griffiths, is regarded as a "second new wave [playwright] of postwar British theatre" (Presada, para. 1). Hare, in the same way as the above-mentioned second-wave playwrights, is also considered as "the cyclical secondwave extension of Osborne's angry Jimmy Porter" (Rusinko,1989, p. 136). Hare, in this sense, may be regarded as the "angry young man" of the seventies frustrated by both of the political wings, disregarded social class issues and the devouring image of capitalism felt throughout the western world. As Billington (2007) states,

in the early Seventies, a new generation began to emerge that was different in all sorts of ways from its immediate predecessors. The new gang, most prominently David Hare and Howard Brenton, had not done National Service [...], had little experience of the workaday world and had not been part of any formal radical grouping. They were alienated by what they saw as the failures of the Wilson government and shocked by the collapse of the Paris student uprising [...]. The new gang [...] were as much intrigued by the spectacle of capitalism in crisis as were dismayed by the failure of Utopian dreams. (p. 215)

It may be argued that the 1960s was a significant decade for Britain and leftist writers in many ways. The failure of Wilson's government as regards socialist change and "pay[ing] even lip-service to radical reform" (Bull, 1984, p. 6) had great impact upon the country. What was more important for the leftist playwrights of the time, however, was especially May 1968 French students' revolution known as "May 68." In May 1968, a large number of students staged demonstrations and occupied many universities in France, which was followed by "general strike and factory- 
occupations." Furthermore, many more strikes and demonstrations were observed throughout the universities and colleges of Western Europe (Bull, 1984, p. x-xi). As Bull (1984) states, "[i]t was a situation that was fermented and stagemanaged not by the traditional organs of political conflict - the unions and political organisations of the working-class but by a young, radical and alienated intelligentsia" (p.10). Bull (1984) also points out that

[s]pecifically, [the revolution] was the determination of the French Communist Party, and the Communist Union, the Confédération Générale du Travail, to deal with the Government along the traditional lines of increased money and decreased working hours, together with the power-seeking prevarications of Mitterand's Socialist Alliance, the Fédération de la Gauche Démocratique et Socialiste, that ruled out the possibility of real political change. (p. 11)

The event, however, resulted in the failure of the student rebellion in Paris. Thus, the year 1968 has become the symbol of "the loss of hope for a socialist revolution" (Rusinko, 1989, p. 136).

This prominent event was not only a social determinant for many western societies but also marked the beginning of "a genuine socialist theatre" (Bigsby, 1993, p. 284) in which David Hare is also included. "Viewed in this way, it is not difficult to start conceiving of the May revolt as a piece of extended street theatre - street theatre which invited participants to play out their contradictions in the world, and which denies any distinction between art and reality" (Bull, 1984, p. 13). Hare has brought this blurred line between art and reality into the theatre which is a very influential instrument for his main purpose of changing society.

As Presada accentuates, "[a]ware of the fact that Agitprop plays failed to change society and the political system, Hare attempted to find new forms of protest" (para. 2). He believes that "theatre must reflect social [and political] reality in extreme forms" (Presada, para. 1). He succeeds in creating "extreme forms" through writing about neglected subjects which, in fact, have many functions in society. He (1991) expresses his interest in these subjects in his book entitled Writing Left-Handed as follows: "I became a writer by default, to fill in the gaps, to work on the areas of the fresco which were simply ignored, or appropriated for the shallowest purposes: rock music, black propaganda, gun-selling, diplomacy" (p. 34). He also emphasises that "all [he] was doing was observing the passing scene, its stridency, its hysteria, its obscenity, and trying to put it in a historical context which the literary community seems pathologically incapable of contemplating" (1991, p. 34).

Together with the above-mentioned social and political problems going on in the 1960s, in Britain, there was also a trend which was "a very eclectic reinscription of traditional and symphonic musical forms within an electric or electronic rock context, with groups such as King Crimson, Jethro Tull, Genesis, Yes, and Emerson, Lake and Palmer" (Straw, 2001, p. 452). Hare, in his 1975-play, Teeth 'n' Smiles, set in 1969, one year after May 1968 event, combines his socialist ideas with this strident music, rock ' $n$ ' roll, which was once "a single unifying symbol of youth rebellion" (Croft, 2005, $p$. 160) against the social and political problems. Hare uses this sort of music efficiently as an instrument for reflecting his criticism upon the ruling intelligentsia and the "glass ceiling" between this ruling middle class and the ruled working class.

Moreover, his grotesque style and the content of his work which is dominated by laughter or cries, strident music and voices and obscene gestures, scenes and languages give the impression of a carnival. In the light of all the abovementioned statements, this paper aims to discuss Hare's political and social criticism in relation to the rebellious rock'n'roll band in his Teeth ' $n$ ' Smiles and Bakhtin's idea of carnivalesque which creates a momentary escape from frustrations.

"Like many other members of what has been described as 'the wild bunch' of leftist dramatists, Hare expands his individual situations to the national level, making them symbols of the bankruptcy of England and of Western civilisation" (Rusinko, 1989, p. 136). He manages to criticise national problems through a microcosmic situation or seemingly insignificant situations and through many symbolic and metaphorical images. Similarly, the ball-room in the Café de Paris, Cambridge represents a microcosmic image of Britain in general. In this corrupt society as reflected in the play, mixed feelings and psychologies of the characters, especially of "the song-writer, Arthur, and the self-destructive singer, Maggie" who reflect the "dialectic of idealism and despair" (Bull, 1984, p. 73) are embodied. The song Maggie sings in the end, "Last Orders," signifies many messages in relation to the condition of this corrupt society. As a matter of fact, the sinking Titanic, depicted in the lyrics of the song, symbolises the sinking British society:

Because the ship is sinking

And time is running out

We got water coming in

Places we don't know about

The tide is rising

It's covering her name 
The ship is sinking

But the music remains the same (Hare, 1992, p. 248)

Britain, depicted as a sinking nation, similar to the Titanic and to the youth of May 68 generation, shows a constant failure, and the play, in this sense, may be argued to "explore the causes of postwar socio-political decline" (Oliva, 1996, p. 208). This failure suggests the need and struggle for an urgent social and political change in society. Hence, what Hare is trying to do via this work is significant: He, "preoccupied by the question of how you live decently inside a corrupt, capitalist world, wanted to change it from within" (Billington, 2007, p.220). His anger stems from not only the disenchantment with the political parties but also the capitalist society in which there is a huge cliff between the rich and the poor that is symbolically represented in Teeth ' $n$ ' Smiles play by the broken plug which symbolises the broken relationship between these two classes. The capitalist mentality is particularly represented by Saraffian, the employer of the band whose main concern is only "cash" (Hare, 1992, p. 229), not the individual rights of his employees. Rich powerful rulers are also harshly criticised by Arthur, who is angry with the system and the rulers, who mirrors his anger mainly through his song lyrics and, who says "the rules are so complicated, it's like three dimensional-chess" (Hare, 1992, p. 214-15). He also says:

[E]veryone told me: don't waste your energy. Because that's what they want. They invent a few rules that don't mean anything so that you can ruin your health trying to change them. Then overnight they re-draft them because they didn't really matter in the first place. One day it's a revolution to say fuck on the bus. Next day it's the only way to get a ticket. That's how the system works. An obstacle course. (Hare, 1992, p. 178-79)

Likewise, his song, "Close To Me," is his inner voice and the reflection of his anger and hatred against the system of rich rulers that he criticises above:

\author{
In a cafe called Disaster \\ Photos of the movie stars \\ Looked down upon the customers \\ As if they came from Mars (Hare, 1992, p. 183)
}

Arthur's arguments and songs, which are, actually, the inner voice of Hare himself, convey significant political messages to the audience/ readers. Throughout the play, the songs serve to question the problems going on in society and the audience/ readers are invited to find an answer to Anson's crucial question: "Would you say the ideas expressed in popular music... have had the desired effect of changing ... society in any way?" (Hare, 1992, p.191). According to Hare, "[a] play is a performance. So if a play is to be a weapon in the class struggle, than that weapon is not going to be the things you are saying; it is the interaction of what you are saying and what the audience is thinking" (Hare, 1991, p. 30). So, Hare, in a way, asks if it is possible to think theatre as "an instrument of change" (Wu, 2000, p. 170) for better. Hence, he, via his works, tries to influence the audience/ readers whom he expects to be sophisticated and make them question the errors observed in Britain rather than accepting them as they are.

In fact, Hare states his desire for an active youth who is not like sheep and is not fooled into believing the false appearances that the capitalist system imposes upon individuals. He is totally against a capitalist system that stealthily imposes its own ideologies upon the individuals by disregarding the citizens' free wills and rights. As regards Hare's views, Havel's following statements in his "The Power of the Powerless" about the false appearances of the powerful system to the powerless individual are meaningful and reflect a bitter satire:

As the interpretation of reality by the power structure, ideology is always subordinated ultimately to the interests of the structure. Therefore, it has a natural tendency to disengage itself from reality, to create a world of appearances, to become ritual. In societies where there is public competition for power and therefore public control of that power, there also exists quite naturally public control of the way that power legitimates itself ideologically. [...]. [T]hus there is nothing to prevent ideology from becoming more and more removed from reality, gradually turning into what it has already become in the post-totalitarian system: a world of appearances, a mere ritual, a formalized language deprived of semantic contact with reality and transformed into a system of ritual signs that replace reality with pseudo-reality. (1978, para. 29)

Hare has always been "concerned with the lies by which his characters live and act" (Rusinko, 1989, p. 135). In relation to Havel's ideas and these lies and falsities, the title of the play, "Teeth and Smiles" may be interpreted as follows: In the environment surrounded by the falsities of the system that falsely reflects everything as "all right," all the citizens of the nation, as a result, live with these lies, and pretend to be so much cheerful that this "teeth and smiles" 
image is observed in them in an ironical way as a false image. Cambridge University, specifically Jesus College, represents a microcosm that stands for the country again. The Graduation Ball where the students enjoy themselves is symbolic in that it stands for the false happiness of the nation. They, in a way, deceive themselves. Their individual freedom is repressed; they, however, are not aware that they also may have some desires of their own. In this sense, these university students serve Hare's social satire. Hare disappointedly states as follows:

\begin{abstract}
I must tell you what I find in universities. I find a generation who are cowed, who seem to have given up on the possibility of change, who seem to think that most of the experiments you could make with the human spirit are likely to be doomed or at any rate highly embarrassing. There is a demeaning nostalgia for the radicalism of the late sixties, people wanting to know exactly what the Vietnam marches were like. To me it would be sad if a whole generation's lives were shaped by the fact that a belief in change had fallen temporarily out of fashion; in Tom Wolfe's terms, it would be sad if this historical period had no chronicler. (1991, p. 35)
\end{abstract}

Similarly, the rich Cambridge students depicted as "[n]arcissists," "[y]ahoos" and "intellectuals" (Hare, 1992, p. 178) are reflected as machines that are programmed to do whatever the system requires without the right to choose. Anson, a medical student, is reflective of such people who cannot manage to take a step forward to be heard due to their fear of the powerful system. His cowardice reflects Havel's idea of "the power of the powerless," which is inefficient in the face of the power of the powerful system, which may be deduced from the following conversation between Maggie and Anson:

Maggie: Yeah. What do you study?

Anson: Oh... medicine.

Maggie: Great.

Anson: Well, yes, in a way except I don't seem very suited. It's not my ... anyway ... I don't want to bore you with my problems.

Maggie: What would you like to be?

Anson: Well... I don't know. If I was free...

(Maggie stares at him.) (Hare, 1992, p.195)

Anson wants free-thinking; freedom as he wants to be an individual, not a part of a restricted system; however, he is too passive to achieve this desire. In another part, he expresses his desire to "[h]ave some character" (Hare, 1992, p. 218-19) and what he really wishes to be and his problematic and boring life as follows:

Anson: I just long to get away. Join a band. On the road. Eh? I wouldn't mind how menial ... anything. It's just every day here I know what the next day will be like. Isn't that dreadful? Going to lectures. Work in the lab. And all the time I want my mind to float free, I want it above me like a kite, and instead it's ... why have I no friends? And why does nobody talk to me? (Hare, 1992, p. 218-19)

Actually, the last lines of the song, "Passing Through," sung by Maggie are very suitable for Anson's passivity and the weird situation he is in: "If you don't scream honey / How do they know you're there" (Hare, 1992, p. 186). These lines may be interpreted in line with Hare's call for active and efficient resistance and an effort first to change oneself and later the society. Hare's following message is felt: The desired change in society is possible only with the initial change in individuals.

As a matter of fact, "the lives of young people in the UK in the postwar era have been characterised on the basis of the rather unholy trinity of 'sex and drugs and rock'n'roll" (Croft, 2005, p.156) as a means of their rebellion. Likewise, the members of the band in Teeth ' $n$ ' Smiles, are, actually, dissidents who present their non-conformist behaviours and resistance towards the status quo/ the Establishment through many instruments such as their choice of music type, that is, rock music; their style (clothes, accessories, behaviours peculiar to the rockers), the ritualistic activities such as use of alcohol, drugs like Valium (Hare, 1992, p. 171) and Preludin, which "enlarges [one's] sexual capacity" (Hare, 1992, p. 176), and sex, and grotesque behaviours which also encode many political and ideological messages. They, in a way, stubbornly and explicitly struggle against the powerful system through crying as "Non-Serviam," that is to say, "I will not serve," which reflects their rejection of serving the nation and its institutions that do not attach importance to the thoughts of its individuals. In this respect, as Oliva states, Hare presents "the effect of public institutions on private lives" (1996, p. 207). Especially Maggie's nonconformist behaviours against the state and its ideological state apparatus, education can be understood from her following words: "[l] had it, this English education. Takes a long time to wipe that particular dogshit off your shoe" (Hare, 1992, p.194). Maggie is also embarrassed at her English identity as she sees England as "a 
sick gnome" (Hare, 1992, p.194), which is revealed by Anson who says "You never seem very happy to have been English" (Hare, 1992, p.194).

Moreover, Maggie's sexual relationship with many "stupid men" (Hare, 1992, p.196), which is very political as it represents "sexualised politics" (Wheeler and Griffiths, 1992, p. 189), and consumption of extreme alcohol and drugs are all her "rituals" through which she protests against the system. Her extreme alcohol consumption may be a constant reminder of the frustrations and it is possible to argue that she does not want to forget her hatred for the Establishment as might be understood from her and Arthur's following expressions: "(She holds up the whisky bottle.) 'This is a depressant, I take it to get depressed"' (Hare, 1992, p. 209), because, as Arthur says, "[s]he doesn't know how to be happy. [...] Her problem is: she's frightened of being happy" (Hare, 1992, p. 242). Aware of the difficulty of change in society, she creates her own self-destructive rituals in which she finds temporary escape from frustrations. She lives in the lonely world she herself has created. In this sense, her behaviours become an exemplary figure of what Stuart Hall and Tony Jefferson call "resistance through rituals" (the title of their book).

For the marginal subcultures, "the language of commodities" (Clarke, Hall, Jefferson and Roberts, 2003, p. 54) should not be ignored as well. As Clarke argues, marginal groups have their own cultural codes. These "distinct" (Clarke, Hall, Jefferson and Roberts, 2003, p. 53) characteristics "consist[...] both of the materials available to the group for the construction of subcultural identities (dress, music, talk), and of their contexts (activities, exploits, places, caffs, dance halls, day-trips, evenings-out, football games, etc)" (Clarke, Hall, Jefferson and Roberts, 2003, p. 53). In Teeth ' $n$ ' Smiles, the members of the band stand out not only with the slang words and rude and offensive language but also with their marginal clothes, accessories and way of life. Inch, for example, is portrayed as a person who "is twenty, in leather and jewellery" (Hare, 1992, p. 167). Arthur "is wearing a silver top hat and a silk suit but the effect is totally discreet" (Hare, 1992, p. 167). Smegs is depicted as a person who "is dressed like a very baggy matelot" (Hare, 1992, p. 170). Moreover, they use motorbike and drive van, which gives the impression of freedom. Bass guitar, a harsh instrument, is also associated with rock ' $n$ ' roll groups, as also observed in the band in the play, which is expressed by Peyote as follows: "I play fuckin' bass guitar" (Hare, 1992, p. 171). This instrument represents resistance and their personalities. In their "domain," via their "subcultural styles," they, in a way, find, in Clarke's terms, "an area of relative freedom" (2003, p. 175) within the rules of the Establishment, the status quo, "traditionalised" (Clarke, 2003, p. 177) codes. They have "'unofficial' styles, where the stylistic core (if there is one) can be located in the expression of a partly-negotiated opposition to the values of the wider society" (Clarke, 2003, p. 177). Their style which reflects this "relative freedom" signifies many meanings that can be understood by this particular group. They do not want anyone from the Establishment to be involved in their personal areas. The song, "Don't Let the Bastards Come Near You," voices their criticism upon and hatred against the corrupt system, their oppositions, their demand for free will, and rebellion against the state's struggle to push marginal groups into uniformity, into being the same with the other machines of the system, their effort to find a place in the centre of the society and to voice themselves, their being black sheep among white sheep:

\section{(Eight single spots come up on Smegs, Wilson, Nash, Peyote, Randolph, Arthur, Laura, Inch as they join in the chorus.) Don't let the bastards come near you \\ They just want to prove you're sane \\ To eat up your magic and change you \\ So I'll help keep the bastards away (Hare, 1992, p. 222)}

Different manners and styles of subcultures they exhibit in their own free domain where they can take pleasure and enjoy their lives create a carnivalesque atmosphere as well. In carnivals, where everybody from each part of a society meets and has fun, and, symbolically, becomes kings or queens for one day, the attendants, again symbolically, vomit their hatred and rebellion against the status quo, and they, in a way, vomit their anger back into the society. As they vomit, they symbolically experience a temporary relief. Similarly, the styles of youth subcultures, or particularly of the rock band in the play, reflect a close relationship with the ones in carnivals. Through their different style, they symbolically vomit their hatred and anger and feel more relaxed. As Stallybrass and White (1986) argue,

[i]n the 'Studies on hysteria' many of the images and symbols which were once the focus of various pleasures in European carnival have become transformed into the morbid symptoms of private terror. Again and again these patients suffer acute attacks of disgust, literally vomiting out horrors and obsessions which look surprisingly like the rotted residue of traditional carnival practices. At the same time, the patients seem to be reaching out, in their highly stylised gestures and discourses, towards a repertoire of carnival material as both expression and support. They attempt to mediate their terrors by enacting private, made-up carnivals. In the absence of social forms they attempt to produce their own by pastiche and parody in an effort to embody semiotically their distress. (p.174) 
Similarly, in the "made-up carnival" atmosphere of Teeth ' $n$ ' Smiles, everybody, white and dark, middle class and working class from everywhere come together to vomit their terror, hatred, distress and horrors: Laura, "a small dark girl with lovely skin" (Hare, 1992, p. 167), Wilson, "small, bearded cockney, and Nash, a spaced-out black drummer" (Hare, 1992, p. 168), middle-class Arthur and working class Peyote. They are here with the diversity of the language of different classes "at battle, or at play" (Brottman, 2005, p. 3). Here, they try to relieve their stress via the songs and musical instruments. In "Don't Let the Bastards Come Near You," similar to the dream world of carnivals whose "mocking forms [...] bring everything down to a single level," (Brottman, 2005, p. 14), rich and powerful rulers are humiliated by the characters. In the carnivalesque atmosphere of this song, rulers' privileged characteristic is taken from them, and they are even called as "bastards."

After the band comes to the campus, their intrusive impact upon the rich college students is felt. The world of the rich is shattered and the wall separating the classes is symbolically demolished throughout the concert and the dream world created by drugs and alcohol and rock 'n' roll. Everybody seems at an equal level, and binary oppositions such as the ruler and the ruled, the upper class and the working class, the rich and the poor are deconstructed. During carnival, "the sacred is profaned, and the relativity of all things is proclaimed. At the time of carnival, everything authoritative, rigid, or serious is subverted, loosened, and mocked" (Brottman, 2005, p. 2). As Bakhtin (1984) states, "[a]s opposed to the official feast, one might say that carnival celebrated temporary liberation from the prevailing truth and from the established order; it marked the suspension of all hierarchical rank, privileges, norms, and prohibitions" (p. 10). Bakhtin (1984) also puts forth that

[a]ll the symbols of the carnival idiom are filled with this pathos of change and renewal, with the sense of the gay relativity of prevailing truths and authorities. We find here a characteristic logic, the peculiar logic of the 'inside out' [...], of the 'turnabout,' of a continual shifting from top to bottom, from front to rear, of numerous parodies and travesties, humiliations, profanations, comic crownings and un-crownings. (p. 11)

It may be stated that the band benefits from the ball atmosphere on their own accounts. Jesus College Ball becomes their carnival atmosphere in which they create their own illusory world where they find an illusory sense of freedom. Especially after Maggie sets fire to the tent as a part of her utopian dream of changing society, they experience a relief due to the fact that an action against the system has been taken. Before this active resistance, their violence is observed only in the lyrics and harsh music they make. This action, however, is the climactic point in the lives of the characters. Everybody is observed to be very cheerful and laughter becomes a part of this carnivalesque atmosphere. Especially Maggie's id is reflected not only physically as she is totally naked after the event but also psychologically through her self-confidence that has been recovered after her brave action and that reveals her resistance to and rebellion against the status quo, which is clear from the conversation between Maggie and Arthur:

Pitch dark. You can see nothing at all. You just hear their voices: Maggie is very cheerful. (Hare, 1992, p. 234)

Arthur: Maggie. Maggie. Are you there?

[...].

Maggie: I'm here. I'm naked and I'm covered in coconut oil.

[...]

(She laughs.)

Arthur: You've done pretty well.

Maggie: Thank you very much.

Arthur: Yip. Police. Ambulance. Fire brigade. You just got to score the air-sea rescue service and you got a full house.

[...]

Maggie (complaining): I can't see any flames.

Arthur: No, no, they're all coping rather well. They all love it you know. Dashing about in the smoke. They're hoping to make it an annual event.

Maggie: Really?

Arthur: Bit of fun. (Hare, 1992, p. 234-35)

[...]

(She shouts into the night.)

Maggie: Nothing's going to stop me. No one. Ever. Let me do what I want.

(She peals with a laughter. [...]) (Hare, 1992, p. 236)

Maggie, in a way, has "evolved from passive victim[...] to active and [...] violent initiator[...] of justice" (Oliva, 1996, p. 214). She is transformed from a self-destructive passive person into an active rebel with a hope for change. "Carnival 
[represents] the true feast of time, the feast of becoming, change, and renewal. It [is] hostile to all that was immortalised and completed" (Bakhtin, 1984, p. 10). Now, she openly resists the dogmatic and unquestionable authoritative rules, and the powerless is transformed into the powerful in an illusory sense, which is mirrored by her grotesque and triumphant laughter. As Bakhtin (1984) underlines, carnival laughter "is ambivalent: it is gay, triumphant, and at the same time mocking, deriding. It asserts and denies, it buries and revives" (p. 11-12), which is also observed in Maggie's abovementioned behaviour.

Due to her brave act, Maggie succeeds in gathering so many people from different classes and parts of the country in the carnivalesque area, in other words, the party environment. A significant ideological state apparatus, the police come along with the ambulance, the fire brigade (Hare, 1992, p. 235), the members of the band representing mainly the working class youth (except for Arthur, a middle class person), the Cambridge students representative of the rich. As Inch says, there are "[a]bout seven 'undred and fifty of 'em. An' all around," "lookin' for [her] (Hare, 1992, p. 237). All these sounds of different sirens coming from police cars, ambulance and the vehicles of the fire brigade that constitute the image of crazy musical entertainment of the Carnival, the voices of people from different classes crying in excitement, anxiety, horror and cheerful and hysterical mood prepare the carnivalesque atmosphere. All these different sounds and voices create a "multiplicity of social voices and their individual expressions" (Brottman, 2005, p. 1), in other words, they create a polyglossia-atmosphere which "is most radical and significant at times of festivity or social unrest, especially in the time [Bakhtin] refers to as carnival" (Brottman, 2005, p. 2). As Bakhtin (1984) states, "[t]he feast [is] a temporary suspension of the entire official system with all its prohibitions and hierarchic barriers. For a short time life [comes] out of its usual, legalised and consecrated furrows and enter[s] the sphere of utopian freedom" (p. 89).

Throughout this illusory atmosphere that Maggie has created, all the characters behave as they wish, and it is possible to clearly hear their individual voices which reflect their grotesque happiness as may be understood from the characters' grotesque laughter (Hare, 1992, p. 241) and from the following expressions of the characters about the event: For Saraffian, "that was fun" (Hare, 1992, p. 237); for Wilson, "[i]t's so stupid it's just wonderful" (Hare, 1992, p. 238), and "[t]hat was the best night [he] 'ad in years" (Hare, 1992, p. 241); for Nash, it "[r]eally brightened up the evenin,"' (Hare, 1992, p. 241); for Peyote, it is "[f]antastic" (Hare, 1992, p. 243) and it has created a different sexual opportunity for him as is clear from his following cheerful expressions: "Fuckin' on a fire engine, you wouldn' believe it" (Hare, 1992, p. 243); for Inch, it creates an opportunity to "come and drag some naked women from the flames" (Hare, 1992, p. 238). The id in terms of sexual desire and the burst of repressed feelings is clearly observed in these scenes. For Bakhtin, "[i]n the grotesque world the id is uncrowned and transformed into a 'funny monster.' When entering this new dimension, even if it is Romantic, we always experience a peculiar gay freedom of thought and imagination" (1984, p. 49). In this illusory world, the dominance of the superego which is valid in the real world is deconstructed.

Arthur, through his aggressive songs, and Maggie, through singing Arthur's songs and burning the tent, try to take action against the status quo; however, Arthur's songs prove to be "as powerless as the band's aggression in the face of the University establishment's ability to soak up anything" (Bull, 1984, p. 75). The efforts of Maggie and Arthur, the only two characters who are politically sensitive, are not enough to change the whole society. "For all the characters, not just the middle class ones, the ball [turns out to be] a cathartic experience which provides a great party and nothing more" (Coates, 1989, p. 69). While Maggie tries to voice herself through her political protest by setting fire, "all around the rest of the band set off on an orgy of looting and sex" (Bull, 1984, p. 75). Moreover, Maggie is disappointed with her friends who are very passive and who betrays her through "stash[ing] all their stuff in [her] bag [during the police bust] [,which] means the bust sort of settles on [her]" (Hare, 1992, p. 228), and due to the betrayal of her friends she is imprisonment in the end. In this respect, the lyrics of Arthur's song near the end are really meaningful as regards telling the condition of the corrupt society where you can trust nobody: "Your good friends always tell you lies/ Doing what your bad friends would never do" (Hare, 1992, p. 245). After the "carnival" and the betrayal of her friends, Maggie is left again with her desperation and continuous suffering. Maggie and Arthur's utopian ideals fail and their dream and metaphorical carnival are over in the end.

In the light of all these discussions, it might be argued that Anson's question about popular music's effect of changing society finds its answer only in the end. Change is possible only when one really believes in it, otherwise, the disillusionment continues and no problem is solved through creating only illusory worlds where one exhibits "an indifference towards serious political questions" (Coates, 1989, p. 69). Under normal conditions, "Teeth ' $n$ ' Smiles" suggests being cheerful and happy; in the play, however, it suggests a great irony. It denotes the idea that "the ineffectiveness and unhappiness of [the] characters is shared by the government and society" (Oliva, 1996, p. 213). The play might be Hare's call for solidarity of the youth with each other rather than passively saying that "[t]he whole system's totally corrupt an's gotta be totally replaced by a totally new system" (Hare, 1992, p. 214). Throughout the play, it is 
possible to hear Hare's voice that asks "whether the criteria by which we have been brought up are right; whether what each of us experiences uniquely really is what makes us valuable; whether every man should really be his own cocktail; or whether our criteria could and should be collective, and if they were, whether we would be any happier" (Hare, 1991, p. 35). Maggie, in a way, stops asking these questions and prefers to experience imprisonment, and expresses her will saying, "I just wanted to go to jail" (Hare, 1992, p. 240), paradoxically, in order to be relieved from the frustration that the rules of the state, the betrayal and passivity of her friends have created. This imprisonment "will give her an experience of suffering which is bound in her eyes to be more worthwhile than the life she could lead outside" (Hare, 1991, p. 34). Her rebellion through the songs, her marginal wearing style, use of drug and consumption of alcohol, her sexual activities, and in the end her active resistance through setting fire creating a carnivalesque atmosphere, which are all indicative of her political protest, give her the chance of only temporary escape from disillusionment. When she is face to face with the reality of corruption, she chooses a life of imprisonment. Hence, her pain goes on and on "[b]ecause the ship is sinking etc" (Hare, 1992, p. 248).

\section{References}

Bakhtin, Mikhail (1984). Rabelais and his world (Helene Iswolsky, Trans.). Bloomington: Indiana UP.

Bigsby, C. W. E. (1993). Contemporary British drama, 1970-90. In Hersh Zeifman and Cynthia Zimmerman (Eds.), The politics of anxiety: Contemporary socialist theatre in England. London: Macmillan.

Billington, Michael (2007). State of the nation: British theatre since 1945. London:Faber and Faber.

Brottman, Mikita (2005). High theory/ low culture. Hampshire: Palgrave Macmillan.

Bull, John (1984). New British political dramatists. London: Macmillan.

Clarke John (2003). Resistance through rituals: Youth subcultures in post-war Britain. In Stuart Hall and Tony Jefferson (Eds.). Style: the creation of style. U. of Birmingham: Routledge.

Clarke, John, Stuart Hall, Tony Jefferson and Brian Roberts (2003). Resistance through rituals: Youth subcultures in post-war Britain. In Stuart Hall and Tony Jefferson (Eds.). Subcultures, cultures, and class. U. of Birmingham: Routledge.

Coates, Stephen (1989). Alien nation: David Hare's History Plays. (Doctoral Dissertation). Retrieved June 5, 2013 from, ir.canterbury.ac.nz/bitstream/10092/4579/1/coates_thesis.pdf.

Croft, Jo (2005). British cultural identities. In Mike Storry and Peter Childs (Eds.) Youth culture and style. London: Routledge.

Hare, David (1992). The early plays: Slag, the great exhibition, teeth 'n' smiles. London: Faber and Faber.

Hare, David (1991). Writing left-handed. London: Faber and Faber.

Havel, Václav (1978). The power of powerless. Retrieved June 25, 2013 from, http://mrdivis.yolasite.com/ resources/Vaclav\%20Havel's\%20Power\%20of\%20the\%20Powerless.pdf.

Oliva, Judy Lee (1996). British playwrights, 1956-1995. In William W. Demastes (Ed.), David Hare. London: Greenwood.

Presada, Diana. David hare: attacking the humanist tradition of social drama. Retrieved May 28, 2013 from, http://www.upm.ro/facultati _departamente/stiinte_litere/conferinte/situl_integrare_europeana/Lucrari/Presada.pdf.

Rusinko, Susan (1989). British drama 1950 to the present: A critical history. Boston: Twayne.

Stallybrass, Peter and Allon White (1986). The politics and poetics of transgression. London: Cambridge UP.

Straw, Will. (2001). The cultural studies reader. In Simon During (Ed.). Characterising rock music culture: the case of heavy metal. London: Routledge.

Wheeler, Wendy J. And Trevor R. Griffiths (1992). The death of the playwright: Modern British drama and literary theory. In Adrian Page (Ed.). Staging 'the other scene': A psychoanalythis approach to contemporary British political drama. London: Macmillan.

Wu, Duncan (2000). Making plays: Interviews with contemporary British dramatists and their directors. N. Y. St. Martin's P. 